DECRETO-LEI N.・ 7.154 - DE 14 DE DEAEMRRO DE 1944

Dispōe sôbre o refime de previdência dos servidores públicos dos Estados, Municipios e Territórios - da Prefeitura do Distrito Federal

- Presidente da República, usando da atribuiçāo que the confere o art. 180 da Constituiçäo, decreta:

Art. 1.० O regime de previdência social instituido para os servidores público civis da Uniāo poderá se aplicar as pessoal a serviço do Estados, Municípios, Distrito Federal e Territórios, mediante acórdo com o Instituto de Previdência - Assistência do servidores do Estado, na forma do Decreto-lei n.0 4.551, de 4-8-42.

Art. 2.० A fim de dar cumprimento ao disposto no artigo anterior, os respectivos Interventores ou Governadores - O Prefeito do Distrito Federal submeterǟo a aprovaçăo do Previdente da República, por intermédio do Ministério da Juntiga e Negbrio Interiores, - projetos de lei que se fizerem necessários, observando, no que couber, os Decretos-leis as. 1.202 , de 8-4-39, $\bullet 5.511$, de $21-5-43$.

140.541 
Art. 3. Eeta Let entra em vigor na data de sua publicaçäo.

Art. 4." Revogan-se as disposiçōes em contrário.

Rio de Jaceiro, 14 de dezenibro de $1944,123 .^{\circ}$ da Independência e 56.* I República.

\section{Getulio Vargas}

Alesandre Marcondes Filho 